\title{
A Contribution to a Better Understanding of Global Land Grabbing's Impact on Employment and Environmental Threats
}

\author{
Laura Castellucci and Marco Arbia \\ Department of Economics and Finance, University of Rome Tor Vergata, Rome 00133, Italy
}

\begin{abstract}
In the last two decades, the global interest on farmland grew at a remarkable pace. As a consequence, million hectares of land exchanged hands. The ways the transfers happened combined with their geographic concentration in Sub-Saharian Africa, have earned the phenomenon the name of "land grab". The agricultural sector considered a "sunset industry" when commodities prices were declining, is now attractive to financial investors. These foreign investments may be good as they may improve agricultural productivity or instead bad as they may benefit only financial investors. Some results in terms of environmental and local communities' worsening conditions have already emerged. This paper aims to investigate what drives the big size transfers of land, to empirically estimate their effects in terms of local employment and to assess the environmental effects produced by the rapid transformation in the use of vast amount of land in terms of $\mathrm{CO}_{2}$ emissions. It is also proposed to use the estimation in terms of local employment impact as a way of distinguishing between foreign direct investment and land grabbing.
\end{abstract}

Key words: Land grabbing, foreign direct investment, land use change, contracts, land rights, $\mathrm{CO}_{2}$ emissions.

\section{Introduction}

According to the development research group of the World Bank [1] and many others, the 2007/2008 commodity price boom triggered a "rush" for land in developing countries. Yet, many affected countries lacked the regulatory infrastructure to cope with such demand and reliable data on investors' performance. In fact, in recent years a combination of events, such as the commodity price boom after years of a declining trend, the energy and finance crises as well as the environmental one and a growing perception of the availability of natural resource as an effective constraint to economic growth, made the interest on farmland to grow at the global level. As a straight forward consequence, million hectares of land exchanged hands with little or no transparency in the terms of the deals, the prices of acquisition, the size of land, local communities involvement and with no capacity of governments even to recognize the situation in terms of property rights (expropriation vs.

Corresponding author: Laura Castellucci, professor, research field: economic policy. voluntary transfers) and to assess the economic viability of the land transfer in terms of consistency with their strategy for development and in terms of environmental sustainability. Accounting for land transfer/acquisition remains contested and controversial as yet, but research literature is increasing. Different figures have circulated, and a land matrix compiled by the International Land Coalition (ILC) ${ }^{1}$ represents at the moment the most used database. In its land matrix, ILC is documenting a total of 203 million hectares as approved or under negotiation between 2000 and $2010^{2}$, while the International Food Policy Research Institute (IFPRI) ${ }^{3}$ estimates that 20 million hectares were exchanged hands between 2005-2009, and the World Bank estimates in 2010 and confirms in 2015 that 45 million hectares were subject to acquisition under this type of

\footnotetext{
${ }^{1} \mathrm{http} / /$ www.landcoalition.org/en/news/land-matrix-new-data -large-scale-land-deals-not-bubble.

2 In fact, ILC has documented transfer of 80 million hectares from 2008 to 2011 and OXFAM suggests 227 million hectares have been allocated in large-scale land deal from 2001 to 2011, underlying that the great majority of the transfers happened after 2008.

${ }^{3}$ IFPRI website: http://www.ifpri.org/.
} 
no transparent deals. Finally, according to Deininger et al. [2], by the end of 2009, such investment covered 56 million hectares of farmland around the world. Furthermore, the ways that the transfers happened combining with their geographic concentration in poor countries of Sub-Saharian Africa and in other developing countries in other continents, have earned the phenomenon the name of "land grab" (the term was apparently coined by Pearce [3]), substituting it for the more neutral but perhaps misleading term "agricultural investments", in use for instance by the World Bank. Thus, the changing trend of the commodity prices and its spike in 2008 are seen as a threat in terms of food security on the part of less developed countries and as an opportunity of investment in farmland on the part of the financial investors of rich countries. The agricultural sector, considered as "sunset industry" when commodities prices were declining, when the trend reversed has become attractive in terms of investment. Two opposite visions are possible. Some may view these foreign investments as good for development, as they may improve agricultural productivity by bringing in more efficient technology, including biotechnology, to replace the backward one used by local communities. Others may hold the view instead that these types of investment may be detrimental both to the local communities' standard of living and to the natural environment [4], mainly through the changing destination of land without any impact assessment study. Added to the second vision is the fact that in the growing literature, some discomforting results in terms of environmental and local communities' worsening conditions seem to prevail. These conclusions, if confirmed, reveal the reasons why "investors" came to acquire the land in this way. And although there is a huge difference between investors that can be named "pioneer" and those that can be named "speculators" [5, 6] and governments face difficulty in choosing how to attract pioneers and keep speculators out of the country, the main reason for investors is never the benefit of local communities and/or the environment. While some country may resort to land grabbing to provide for food security for their own population (for example Saudi Arabia) and some other just for pure financial speculations, local economic conditions are a concern only for local governments. The environmental conditions, which are concerns for the global community, are completely overlooked by both investors and host country's governments. For this reason, the global community has to investigate more the land grabbing phenomenon and to take a common position to respond to this threat. So far, a skeptical view on the possibility of development for the grabbed countries seems to be supported by the results of the available empirical studies, Ethiopia being the most studied country [7, 8]. But the differences among experiences are so huge to call for a deepening of research. In fact, "improving available databases has to be addressed on a priority basis to make reliable inferences on land sizes, proposed investment volumes, job creation, business models and implementation progress in a consistent and meaningful way. Without these inferences, it will be difficult to allow countries and investors to draw lessons from successful and unsuccessful experiences" [6]. Within the sketched framework, this paper aims to empirically test the main theoretical findings on the basis of available data and to assess the environmental effects induced by big size transfers of land. These transfers of land, greatly accelerating since 2005, may represent a big threat for the environment, as it coincides with a rapid transformation in the use of a vast amount of land. These uses include the changing destination of the land from forest to farmland and the changes from staple crop to cash crop. According to some analyst, "the rate, at which land grabbing consumes large quantities of physical space, destabilizes functioning in environmental and social systems alike" [4]. The risk for the global community stemming from deforestation is well documented. In principle, the change in use could be more favorable to the environmental services production, such as $\mathrm{CO}_{2}$ capture, but in fact a worsening of the environmental conditions is more likely than the reverse, as the environmental regulations in developing countries are less stringent and the pollution-haven hypothesis is still very much alive [9-11]. 

Impact on Employment and Environmental Threats

The aim of the paper is twofold. The first one is an attempt to identifying foreign direct investments (FDI) and in fact land grabbing, and the second is an attempt to provide impact estimation on local employment and on $\mathrm{CO}_{2}$ emissions coming from such FDI.

\section{Addressing the Problem of Identifying Foreign Direct Investment as Opposed to Land Grabbing}

Although to distinguish between "genuine" foreign investment and land grabbing may be a daring task, it is precisely what host countries must do before signing contracts concerning foreign land acquisition. In the first case, they are entitled to expect a positive effect on their GDP growth and/or on the level of domestic employment, while no such economic local benefits follow in the second case. Moreover in the case of land grabbing, a worsening of environmental condition both at local and global level may be expected, as the land grabber does not care about local deterioration/pollution and also about global $\mathrm{CO}_{2}$ emissions stemming from the changing destination of land. In this view, at least two different approaches to assess whether we are in presence of genuine foreign investment or of land grabbing are viable, and reinforce each other. One way relies on the scrutiny of the draft contracts. The quality of the deals in terms of transparency and clearness, consideration or lack of consideration of local population interests, land rights definitions, etc., besides the quality of the state ${ }^{4}$, may signal whether the in principle much needed additional investments in agriculture will entail some benefits for the developing (host) country or instead they will simply bring profits to the investors and/or they simply ensure foreign country food supply. Another way looks at the economic features and tries

\footnotetext{
${ }^{4}$ This is a very important aspect, because in the rush for land the states have a big role to play. It has been underlined that most of the contracts were signed in countries with disorganized and fragile states. Not surprisingly, putting the blame for land grabbing on poor quality of the government, improving governance appears to be the key target for the international community to contribute at avoiding land grabbing [12]. Being in total agreement with this position, simply add the necessity of an economic investigation in terms of results stemming from the many different deals and affecting in different ways, employment, GDP, productivity and the like.
}

to evaluate the economic impacts of such contracts. The presumption is that in the case of FDI, some positive effects in terms of a greater production of staple local food and/or of an increase in productivity, employment or GDP in the host country will emerge, while if nothing of the type emerges, the foreign land acquisition represents in fact land grabbing. The attempt is to precisely estimate foreign land acquisition economic effects in the developing (host) countries as a convincing way of going beyond the rhetoric of land grabbing, more precisely, to look for the impact on local employment as a measure of benefits accruing to the host country (while we are also working on the estimation of the impact on agricultural productivity ${ }^{5}$ ). If no such benefits can be found, the acquisition of land is proposed to be considered just as a land grabbing phenomenon, or in other words, as a modern day form of new corporate colonialism ${ }^{6}$. Of course the lack of economic benefits goes generally hand in hand with the poor quality of the contracts, confirming that the two approaches reinforce each other.

\section{Testing for Land Grabbing Hypothesis on 26 Countries Impact in Terms of Local Employment}

As a first step in our empirical exercise, we look for a statistical relation between agriculture FDI and local employment in the sector, through a panel data model concerning 26 countries $^{7}$ with recorded land transfer

\footnotetext{
${ }^{5}$ Actually to know the impact on productivity stemming from foreign direct investment would complement the information on employment and this is why this estimation is done. It is interesting to know that according to a systematic review, government intervention to enhance security of land tenure would have a positive effect on productivity and farm income or welfare. Of course "tenure security alone is not a 'silver bullet' leading directly to higher farmer incomes”, but it is an important factor or a pre-condition [13].

6 The term is mainly used by social commentators, NGO research institutions, journalists and the like [14].

${ }^{7}$ Which are Argentina, Bangladesh, Brazil, Cambodia, Chile, Costa Rica, Ecuador, Egypt, El Salvador, Ethiopia, Ghana, Honduras, Indonesia, Laos, Madagascar, Malawi, Malaysia, Mozambique, Nicaragua, Pakistan, Philippines, Tanzania, Thailand, Tunisia, Uganda, Vietnam. Notice that several countries are outside the African continent; in fact the phenomenon of land grabbing is not an African phenomenon but it is rather an international/global one.
} 
deals and 21 years of observation (1992-2012). FAO dataset has been used for all the variables concerning the agriculture sector, while World Bank data, namely world development indicators, have been used for all the others.

To estimate the impacts on local employment on the agricultural sector, the following regression equation has been specified, as Eq. (1):

$$
\ln _{-} L_{i, t}=\alpha_{i}+\beta f d i_{-} a_{i, t}+\boldsymbol{\omega} \boldsymbol{X}_{i, t}+\gamma_{t}+\varepsilon_{i, t}
$$

Where, $\boldsymbol{\omega}$-vector of variables coefficients in the conditioning set; $\alpha_{i, t}$-equation intercept; $\beta$-coefficient of variable; $\gamma_{t}$ —coefficient to capture time effects; $\varepsilon_{i, t}$ - error term.

The dependent variable is the level of agricultural employment $\left(l_{-} L\right)$, measured through the number of workers employed in the sector. The first and most important independent variable is the stock of foreign direct investment in the agriculture sector as percentage of GDP (fdi_agri), as the paper's object is to investigate whether a statistically significant relation between the two variables exists. The other independent variables, which constitute the conditioning set $\left(\boldsymbol{X}_{\boldsymbol{i}, \boldsymbol{t}}\right)$ are the following:

(1) First, the agricultural production (logarithm) (In_prodragri). It is given by the value of total gross product of the sector at constant market prices (2005 US\$);

(2) Second, the total factor productivity (tfp) of the sector. It is a ratio between total output and total inputs in the specification by Chambers [15], and it allows to measure the effect of an increase of productivity in the sector on the local employment;

(3) Third, the logarithm of the remaining production inputs, capital and land: $\ln \_K$ and $l n \_l a n d$. The value of the stock of capital is considered at constant prices, while the extension of farmland in thousands of hectares enters the picture as land input. Moreover, since foreign direct investments in different sectors, such as the mining sector, the industrial and the services' ones, may produce externalities in the agricultural sector, three variables are used to account for these possibilities. Therefore, the stock of foreign direct investment (as percentage of GDP) in the primary sector, industrial sector (or secondary) and services' sector (or tertiary) is considered through the variables: FDI_prim, FDI_sec and FDI_ter;

(4) Moreover, another variable linked to the education level of the population ( $a v$ sschooling). Such education level is measured by the average number of years of education. It is reasonable to expect that people more educated will try to find highest-paid jobs, which usually are not in the agricultural sector;

(5) Finally, the control variables for food security and population growth, $f s i$ and rpop_growth, respectively. The first is defined by means of an index of country food deficit in terms of calories per person per day necessary to get rid of malnutrition, while the second one coincides with the annual rate of growth of rural population. Better food conditions allow more people to be eligible for working position, but the effect on the effective workforce is questionable. The same happens for a growing population; when more people are living in an area, it is reasonable to expect an increase on the level of employment if the supply of work and the demand for work exactly match. But the final effect is uncertain and it depends on the way FDI are used to.

Results from the regression analysis conducted through a fixed effects model, as the Hausman test suggests to be the preferred one, are the following. First, a positive relation between employment and foreign direct investment emerges but with no significance. Other positive relations have been found with respect to agricultural production, capital and food security, respectively, with $1 \%, 5 \%$ and $1 \%$ significance. On one hand, the results from this review are in line with the literature underlying the crucial role of foreign investments for development. On the other hand, they show that a productivity increase as well as an extension of cultivated land reduces the number of local people employed (with 1\% and 5\% significance, respectively). The impact of the variable $t f p$ can be explained with the hypothesis that increased productivity drives to a decreasing level of employment, because there is less need of workers to get the same level of production, while the negative effect on local employment of the extension of cultivated land can be explained by the fact that 

Impact on Employment and Environmental Threats

foreign corporations invest only in large size of land and use mechanized production processes requiring a more skilled labor force than the local workers.

\section{Testing for $\mathrm{CO}_{2}$ Emissions}

By means of the same countries sample, same reference years and same data source, $\mathrm{CO}_{2}$ emissions are tested by following regression Eq. (2):

$$
\begin{gathered}
\text { In_ }_{-} \mathrm{CO}_{2} \text { emissions }_{\mathrm{i}, \mathrm{t}}=\alpha_{i}+\beta f d i_{a_{i, t}} \\
+\boldsymbol{\omega} \boldsymbol{X}_{\boldsymbol{i}, \boldsymbol{t}}+\gamma_{t}+\varepsilon_{t}
\end{gathered}
$$

The dependent variable is the logarithm of pollution emissions measured in terms of gigagrams of $\mathrm{CO}_{2}$ equivalent, while the first independent variable is still given by direct foreign investment in the agricultural sector as percentage of GDP. Other independent variables are the agricultural product, factor inputs of the sector as in the local employment's analysis, direct foreign investment in the other sectors and the population rate of growth. Two more variables have been added: the first one is trade as a measure of the openness of the countries given by import-export balance in percentage of GDP; the second one is forest in terms of hectares of land covered by forest in each country, represented by its logarithm. Needless to say that this variable is very important with respect to emissions for the carbon sink function forests play, but also for the fact, already mentioned, that foreign direct investment-land grabbing generally expand farmland to the expense of the forests. The climate threat poses by deforestation is so well $\mathrm{known}^{8}$, as it seems to be unstoppable, for

\footnotetext{
${ }^{8}$ Forest economics and management is an important topic in natural resource economics nowadays and its importance is fast growing, since the widespread recognition that the value of a forest does not coincide with its timber value. Forests have value other than for timber, for carbon sequestration, soil protection, recreational activities, the habitat provision of plant, animal and (in some cases) human-being, biodiversity conservation, etc. Not surprisingly, for the forests to continue to provide goods and services whose benefits affect the global community, an effective global public policy is necessary. Various instruments are used or recommended. They go from the standard ones as taxes, regulations and subsidies to the more specific and recent ones, such as changes in property rights, certification and international carbon offset. A REDD regime as a means of compensating developing countries for their reductions in emission from deforestation and forest degradation has been discussed since 2005. In the Copenhagen Climate Summit (2009), forest conservation and enhancement
}

that nowadays the commercial use of land always prevails over the shared interests use.

Results from our regression analysis conducted through a fixed effects model, as Hausman test suggests, are all in the direction of signaling a worsening of environmental conditions. The positive coefficient found for the foreign direct investment, with $1 \%$ significance, underlines the emissions increase following these investments. The same is true for the level of production and for the capital used with $5 \%$ and $1 \%$ significance, respectively. Again an easy explanation can be found in the mechanization of the sector which implies fossil fuels use and therefore more $\mathrm{CO}_{2}$ emissions. To confirm the analysis, control variables, related to forest extension and rural population growth, can also be checked. The first one shows a negative coefficient, with $5 \%$ significance, which confirms the importance of the forest as provider of a beneficial effect on the mitigation of global warming. The second one, instead, shows that growing population leads to an increase in $\mathrm{CO}_{2}$ emissions due to the greater consumption of wood products and to the increased production of waste.

\section{Policy Implications for a Global World}

As far as the global community pretends to pursue several goals as to halving poverty if not totally eradicate it and to grant access to safe water to millions of world inhabitants actually deprived of it, the interest has to been taken in the phenomenon of million hectares of land exchanging hands with no transparency in the deals and with no benefits for the local people. While foreign direct investment may be a solution to countries' development, land grabbing is just the opposite. It aggravates local problems and allows a perverse wealth redistribution from poor countries to the richest. In other words, when the changing hands of land is in fact a grabbing event, according to the two mentioned ways of assessing it or to alternative methods, the positive consequences are only on the grabber corporation country side, either in terms of good results from financial speculation

of forests stocks were added to the regime which became known as REDD+ [16-20]. 
and/or in terms of securing the type of crops necessary to its exports and to its domestic demand nowadays, when the land (and water) scarcity is becoming more and more evident ${ }^{9}$. In a world with 7 billion and 300 million people expected to reach 9 billion in 2050, land allocation is indeed a global problem [21]. Moreover, the changing use of land, namely from forest to farm and from one type of crop to another, that regularly follows a land grabbing event, aggravates global emissions of green house gas emissions (or $\mathrm{CO}_{2}$ equivalent), which is another global problem. Actually, after the November 2014 meeting between USA and China $^{10}$ to take action against global warming, i.e., climate change, and the 21st conference of parties (COP) on December 2015 in Paris $^{11}$ to renegotiate the Kyoto protocol, the global community seems determined not to leave the problem unaddressed. Under this respect, it is totally inconsistent not to take position with respect to land grabbing with the aim of avoiding it or at least start to regulate it through an international body ${ }^{12}$ acting as a third party to secure fairness in the deals. The inconsistency for the global community of not taking position with respect to big size land transfers, usually followed by a change in the use of land (not only from forest to farmland but also from staple food crops to cash crops) has robust roots in the consolidated economic theory of optimal provision of public non commercial goods at least since Samuelson 1954 seminal article [22]. The market mechanism is capable

\footnotetext{
${ }^{9}$ It was detected long ago even outside natural resource economists, as the following amusing quotation of Mark Twain explains: "Buy land. They are not making it any more" [3].

10 Mark Lander. "U.S. and China Reach Climate Accord after Months of Talks." NY times, November 11, 2014. https://www.nytimes.com/2014/11/12/world/asia/china-us-xi-o bama-apec.html?_r=0.

11 For further information, see the website of the 21st Conference of Parties of the United Nations Framework Convention on Climate Change. http://unfccc.int/meetings/paris_nov_2015/meeting/8926.php.

12 To this end, it is not necessary to establish an ad hoc administration. The world bank or UNEP could function as the third party in charge of giving its approval to contracts as "fair" ones or to refuse it on the basis of several reasons, such as lack of transparency, benefits for the local population and environmental impact assessment, etc. Although to make the request of approval compulsory may prove to be difficult (if not impossible at least in the short run), a voluntary request would be helpful in discouraging the worst practices.
}

of providing the society with the optimal solution when private, rival and excludable goods are concerned. But when public goods, or even private goods with externalities, are concerned, the market mechanism is unable to reach the Pareto optimum (market failure). Now, it may be admitted that the phenomenon of land grabbing is indeed a market answer to a public global problem. The problem is represented by the growing scarcity of land, which is a given and exhaustible natural resources whose scarcity is growing at a pace given by the needs of a growing population, a growing GDP per capita and the connected changes in the consumption pattern. Market allocation is non-optimal for the society as a whole. Public intervention is therefore necessary for two strong different reasons. The first one is concerned with the global externalities given by increases in $\mathrm{CO}_{2}$ emissions and the second one by the far from optimal allocation of a depletable natural resource, such as land.

Beyond the rhetoric, action is necessary and the delay has a growing $\operatorname{cost}^{13}$. And while the delay is common to the two cases, the global community has recognized long ago that the $\mathrm{CO}_{2}$ emissions is a global public bad and is trying to implement international shared policies to solve the problem (Kyoto protocol and the recent accord of Parigi being the most important examples), for the scarcity of land, the international community has yet to recognize it as an international public problem. To intervene in the private deals to make them fair for the parties directly involved and less detrimental to the global society could be a first step in the right direction.

\section{Conclusions}

This paper is an attempt to better understand land grabbing's impacts on the grabbed country and on the

\footnotetext{
13 The cost of inaction has been underscored more than 10 years ago by the well known "Stern Review on the Economics of Climate Change”, 2006. Since then, several studies have produced estimation of such costs. Different ways of calculating it have been proposed/adopted, but the important thing to notice is that notwithstanding differences in methods and approaches a consensus emerges on the fact that the cost of waiting (inaction) in implementing policies response is growing with the time. One way of measuring it may be that of looking at the marginal damage costs of greenhouse gas emissions and this costs are clearly growing with time [23].
} 

Impact on Employment and Environmental Threats

environment. As such, it belongs to the growing literature on large-scale agricultural land acquisitions, and it does not enter the issues of "sustainable and equitable management" of foreign land acquisition even though it overlaps with the literature on environmental impacts, which in this paper are estimated in terms of $\mathrm{CO}_{2}$ emissions only. The paper does not address the problem of whether agricultural investments are needed, but it estimates the impacts of documented large size land acquisitions. So the paper proposes to use the impact estimation on employment as a way of identifying the phenomenon of land grabbing and the consequences for the global community in terms of $\mathrm{CO}_{2}$ emissions as a way of quantifying externalities. The results suggest that by and large, the positive effect on agricultural production stemming from a larger capital input confirms the literature on development that is in general in favor of foreign investments. On the other hand, the negative impact on local employment when found, may be the consequence of corporations' choices to acquire huge arable land that can only be mechanized, therefore implying a less labor intensive way of production and/or implying a more skilled labor force than the local one. Finally, the worsening of environmental conditions provide the legitimacy for the global community to take interest and possibly action to solve the problem.

In conclusion, if global community does have the goals of enhancing food security for the poor countries, providing access to safe water to millions people still deprived and mitigating global warming, it can not be blind with respect to land grabbing, when it appears. Consistency in the global policy would be enhanced by putting an international body, such as UNEP for example or others, in charge of helping the parties to make fair contracts. Natural resource economists know all too well the risks of leaving to the market the allocation of such fundamental natural resources as land (and water).

\section{References}

[1] World Bank. 2015. “Using National Statistics to Increase Transparency of Large Land Acquisition.” Policy
Research Working Paper No. 7342. Accessed June 26, $2015 . \quad$ http://documents.worldbank.org/curated/en/ 105651467997607338/pdf/WPS7342.pdf.

[2] Deininger, K., Byerlee, D., Lindsay, J., Norton, A., Selod, H., and Stickler, M. 2011. Rising Global Interest in Farmland: Can It Yield Sustainable and Equitable Benefits? Washington: World Bank.

[3] Pearce, F. 2013. The Landgrabbers: The New Fight over Who Owns the Earth. U.K.: Eden Project Books.

[4] Lazarus, E. D. 2014, "Land Grabbing as a Driver of Environmental Change.” AREA 46 (1): 74-82.

[5] Collier, P., and Venables, A. J. 2011. "Land Deals in Africa: Pioneers and Speculators.” Center for Economic and Policy Research (CEPR) Discussion Paper DP8644. Accessed November, 2011. http://cepr.org/active/ publications/discussion_papers/dp.php?dpno=8644.

[6] Arezki, R., Deininger, K., and Selod, H. 2015. "What Drives the Global Land Rush?” World Bank Economic Review 29 (2): 207-33.

[7] Rahmato, D. 2011. "Land to Investors: Large-Scale Land Transfers in Ethiopia.” Forum for Social Studies. Accessed June, 2011. http://www.landgovernance.org/system/files/Ethiopia_Ra hmato_FSS_0.pdf.

[8] The Oakland Institute. 2011. "Land Rights.” https://www.oaklandinstitute.org/land-rights-issue.

[9] Field, B. C., and Field, M. K. 2002. Environmental Economics: An Introduction. New York: McGraw-Hill.

[10] Mabey, N., and McNally, R. 1999. Foreign Direct Investment and the Environment: From Pollution Havens to Sustainable Development. WWF-UK Report.

[11] Neumayer, E. 2001. "Pollution Havens: An Analysis of Policy Options for Dealing with an Elusive Phenomenon.” Journal of Environment and Development 10 (2): 147-77.

[12] Wolford, W., Borras, S. M., Hall, R., Scoones, I., and White, B. 2013. Governing Global land Deals: The Role of the State in the Rush for Land. Oxford: Wiley-Blackwell.

[13] Lawry, S., Samii, C., Hall, R., Leopold, A., Hornoby, D., and Mtero, F. 2014. "The Impact of Land Property Rights Interventions on Investment and Agricultural Productivity in Developing Countries: A Systematic Review." Campbell Systematic Reviews. doi:10.4073/csr.2014.1.

[14] Liberti, S., and Flannelly, E. 2013. Land Grabbing: Journeys in the New Colonialism. London: Verso.

[15] Chambers, R. G. 1988. Applied Production Analysis: A Dual Approach. CA: Cambridge University Press.

[16] Field, B. 2005. Natural Resource Economics. Long Grove, Illinois: Waveland Press.

[17] Sterner, T., and Coria, J. 2012. Policy Instruments for Environmental and Natural Resource Management. Washington: Resources for the Future.

[18] Angelsen, A., Boucher, D., Brown, S., Merckx, V., Streck, C., and Zarin, D. 2011. "Guidelines for REDD+ 
Reference Levels: Principles and Recommendations.” Meridian Institute. Accessed November, 2011. http://www.redd-oar.org/links/REED+RL.pdf.

[19] Intergovernmental Panel on Climate Change (IPCC). 2003. Good Practice Guidance for Land Use, Land Use Change and Forestry, edited by Penman, J., Gytarsky, M., Hiraishi, T., Krug, T., Kruger, D., Pipatti, R., Buendia, L., Miwa, K., Ngara, T., Tanabe, K., and Wagner, F. Japan: Institute for Global Environmental Strategies (IGES).

[20] Angelsen, A., Brockhaus, M., Sunderlin, W. D., and Verchot, L. 2012. Analysing REDD+: Challenges and
Choices. Bogor, Indonesia: Center for International Forestry Research (CIFOR).

[21] Lambin, E. F., and Meyfroidt, P. 2011. “Global Land Use Change, Economic Globalization and the Looming Land Scarcity.” Proc. Nat. Acad. Sci. USA 108 (9): 3465-72.

[22] Samuelson, P. A. 1954. "The Pure Theory of Public Expenditure.” The Review of Economics and Statistics 36 (4): 387-9.

[23] Tol, R. S. J. 2014. Climate Economics: Economics Analysis of Climate, Climate Change and Climate Policy. Cheltenham, UK: Edward Elgar Publishing. 


\section{Impact on Employment and Environmental Threats}

Appendices

Table 1 Impact on local employment.

\begin{tabular}{|c|c|c|c|c|c|}
\hline \multicolumn{3}{|c|}{ Fixed-effects within regression } & \multicolumn{3}{|c|}{ Talues } \\
\hline \multicolumn{3}{|c|}{ Number of observations } & \multicolumn{3}{|c|}{152} \\
\hline \multicolumn{3}{|c|}{ Group variable: number of country } & \multicolumn{3}{|c|}{15} \\
\hline \multicolumn{3}{|c|}{ Observations per group } & \multicolumn{3}{|c|}{$2 \min$} \\
\hline \multicolumn{3}{|c|}{ R-sq within fixed-effects } & \multicolumn{3}{|c|}{0.4258} \\
\hline \multicolumn{3}{|c|}{ R-sq between fixed-effects } & \multicolumn{3}{|c|}{0.5013} \\
\hline \multicolumn{3}{|c|}{ R-sq overall fixed-effects } & \multicolumn{3}{|c|}{0.6636} \\
\hline \multicolumn{3}{|l|}{ Average } & \multicolumn{3}{|c|}{10.1} \\
\hline \multicolumn{3}{|l|}{ Max } & \multicolumn{3}{|c|}{15.0} \\
\hline \multicolumn{3}{|l|}{$F(11,126)$} & \multicolumn{3}{|c|}{8.50} \\
\hline \multicolumn{3}{|l|}{ Corr (u_i, Xb) } & \multicolumn{3}{|c|}{0.4859} \\
\hline \multicolumn{3}{|l|}{ Prob $>F$} & \multicolumn{3}{|c|}{0.0000} \\
\hline \multirow{2}{*}{$\begin{array}{l}\text { Independent } \\
\text { variable }\end{array}$} & \multicolumn{5}{|c|}{ Impact on local employment $\left(\ln \__{-} L\right)$} \\
\hline & Coefficient & Standard error & $t$ & $P>t$ & 95\% confidence interval \\
\hline ln_prodagri & 0.5383778 & 0.1050176 & 5.13 & 0.000 & {$[0.3305511,0.7462045]$} \\
\hline tfp & -0.1983579 & 0.0847073 & -2.34 & 0.021 & {$[-0.3659911,-0.0307247]$} \\
\hline ln_K & 0.4940169 & 0.2376873 & 2.08 & 0.040 & {$[0.0236408,0.9643931]$} \\
\hline ln_land & -0.291739 & 0.1115168 & -2.62 & 0.010 & {$[-0.5124274,-0.0710505]$} \\
\hline FDI_agri & 5.4770310 & 4.6150430 & 1.19 & 0.238 & {$[-3.6560040,14.6100700]$} \\
\hline FDI_prim & 0.3573483 & 1.1061870 & 0.32 & 0.747 & {$[-1.8317630,2.5464600]$} \\
\hline FDI_sec & 1.3614980 & 2.1369210 & 0.64 & 0.525 & {$[-2.8674070,5.5904020]$} \\
\hline FDI_ter & 0.9277828 & 0.8958799 & 1.04 & 0.302 & {$[-0.8451371,2.7007030]$} \\
\hline ln_school & -0.2273098 & 0.1380104 & -1.65 & 0.102 & {$[-0.5004284,0.0458088]$} \\
\hline Fsi & 0.0095464 & 0.0022691 & 4.21 & 0.000 & {$[0.0050559,0.0140368]$} \\
\hline rpop_growth & 0.0178644 & 0.0169885 & 1.05 & 0.295 & {$[-0.0157554,0.0514842]$} \\
\hline _cons & 0.8161269 & 2.0128600 & 0.41 & 0.686 & {$[-3.1672640,4.7995180]$} \\
\hline \multicolumn{2}{|l|}{ sigma_u } & \multicolumn{4}{|l|}{1.4849312} \\
\hline \multicolumn{2}{|l|}{ sigma_u } & \multicolumn{4}{|l|}{0.08828967} \\
\hline \multicolumn{2}{|l|}{ rho } & 0.99647731 (fractio & f varian & due to $\mathrm{l}$ & \\
\hline$F$ test & & $1 \_\mathrm{i}=0 ; F(14,126)$ & 504.15; & $\mathrm{b}>F=$ & \\
\hline
\end{tabular}


Table 2 Impact on $\mathrm{CO}_{2}$ emissions.

\begin{tabular}{|c|c|c|c|c|c|}
\hline \multicolumn{3}{|c|}{ Fixed-effects within regression } & \multicolumn{3}{|c|}{ alues } \\
\hline \multicolumn{3}{|c|}{ Number of observations } & \multicolumn{3}{|c|}{172} \\
\hline \multicolumn{3}{|c|}{ Group variable: number of country } & \multicolumn{3}{|c|}{20} \\
\hline \multicolumn{3}{|c|}{ Observations per group } & \multicolumn{3}{|c|}{$1 \mathrm{~min}$} \\
\hline \multicolumn{3}{|c|}{ R-sq within fixed-effects } & \multicolumn{3}{|c|}{0.6967} \\
\hline \multicolumn{3}{|c|}{ R-sq between fixed-effects } & \multicolumn{3}{|c|}{0.3281} \\
\hline \multicolumn{3}{|c|}{ R-sq overall fixed-effects } & \multicolumn{3}{|c|}{0.4858} \\
\hline \multicolumn{3}{|l|}{ Average } & \multicolumn{3}{|c|}{8.6} \\
\hline \multicolumn{3}{|l|}{ Max } & \multicolumn{3}{|c|}{16.0} \\
\hline \multicolumn{3}{|l|}{$F(11,141)$} & \multicolumn{3}{|c|}{29.44} \\
\hline \multicolumn{3}{|l|}{ Corr (u_i, Xb) } & \multicolumn{3}{|c|}{0.1364} \\
\hline \multicolumn{3}{|l|}{ Prob $>F$} & \multicolumn{3}{|c|}{0.0000} \\
\hline \multirow{2}{*}{$\begin{array}{l}\text { Independent } \\
\text { variable }\end{array}$} & \multicolumn{5}{|c|}{ Impact on $\mathrm{CO}_{2}$ emissions (ln_CO $\mathrm{CO}_{2}$ emi) } \\
\hline & Coefficient & Standard error & $t$ & $P>\mathrm{t}$ & 95\% confidence interval \\
\hline ln_prodagri & 0.1768390 & 0.0554316 & 3.19 & 0.002 & {$[0.0672545,0.2864235]$} \\
\hline ln_K & 0.9442927 & 0.1417443 & 6.66 & 0.000 & {$[0.6640740,1.2245110]$} \\
\hline ln_L & -0.0615709 & 0.0464326 & -1.33 & 0.187 & {$[-0.1533649,0.0302231]$} \\
\hline ln_land & -0.3209348 & 0.0708722 & -4.53 & 0.000 & {$[-0.4610442,-0.1808253]$} \\
\hline FDI_agri & 10.345880 & 2.568059 & 4.03 & 0.000 & {$[5.2690050,15.4227600]$} \\
\hline FDI_prim & -0.1554422 & 0.6941026 & -0.22 & 0.823 & {$[-1.5276350,1.2167510]$} \\
\hline FDI_sec & -1.3741430 & 1.2669240 & -1.08 & 0.280 & {$[-3.8787640,1.1304790]$} \\
\hline FDI_ter & -0.4878571 & 0.5252907 & -0.93 & 0.355 & {$[-1.5263210,0.5506065]$} \\
\hline Trade & 0.0002325 & 0.0005123 & 0.45 & 0.651 & {$[-0.0007804,0.0012453]$} \\
\hline Forest & -0.248893 & 0.1243884 & -2.00 & 0.047 & {$[-0.4948004,-0.0029856]$} \\
\hline rpop_growth & 0.0548217 & 0.0097153 & 5.64 & 0.000 & {$[0.0356152,0.0740282]$} \\
\hline _cons & 4.3315850 & 1.9810670 & 2.19 & 0.030 & {$[0.4151524,8.2480180]$} \\
\hline sigma_u & \multicolumn{5}{|l|}{1.130452} \\
\hline sigma_e & \multicolumn{5}{|l|}{0.05388321} \\
\hline rho & \multicolumn{5}{|c|}{0.99773318 (fraction of variance due to $\mathrm{u} \_\mathrm{i}$ ) } \\
\hline$F$ test & \multicolumn{5}{|c|}{$\mathrm{u} \_\mathrm{i}=0 ; F(19,141)=58.24 ;$ Prob $>F=0.0000$} \\
\hline
\end{tabular}

